\title{
KonRAD TADAJCZYK
}

\author{
Uniwersytet Łódzki
}

\section{'EPISTULAE HADRIANI AD APHRODISIENSES' LISTY HADRIANA DO AFRODYZYJCZYKÓW}

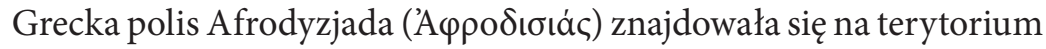
Karii ${ }^{1}$. Miasto weszło w skład prowincji Azji po zapisaniu w testamencie ludowi rzymskiemu królestwa Pergamonu przez Attalosa III, ostatniego króla, zmarłego w roku 133 przed Chr. W czasie długotrwałej wojny Republiki Rzymskiej z Mitrydatesem VI, królem Pontu, Afrodyzjada opowiedziała się po stronie Rzymian, którzy docenili lojalność jej mieszkańców. Ojkonim pochodzi od imienia bogini Afrodyty, której świątynia znajdowała się w mieście. Rzymianie, którzy - według tradycji - wywodzili się od Eneasza, syna Afrodyty, nadali miastu wiele przywilejów,

1 Ch. Ratté, The founding of Afrodisias, «JRA Suppl.» 70/2008, s. 7. W polskiej literaturze naukowej są stosowane trzy egzonimy: Afrodyzjada, Afrodizjas, Aphrodisias oraz Afrodyzja. Pierwszą nazwę, którą uważam za najbardziej adekwatną, stosuje Mieczysław Brożek, zob. Tytus Liwiusz, Dzieje Rzymu od założenia miasta, księgi XXXV-XL, M. Brożek (przekład), M. BrożeK, J. Wolski (komentarz), Wrocław-Warszawa-Kraków-Gdańsk-Łódź 1981, s. 141, 405. Wersję Afrodizjas, połowicznie tylko zaadaptowaną do norm języka polskiego, stosuje Janina Niemirska-Pliszczyńska, zob. W świątyni i w micie. Z Pauzaniasza Wędrówki po Helladzie księgi I, II, III i VII, J. Niemirska-Pliszczý́ska (przekład i komentarz), B. Filarska (komentarz archeologiczny), Wrocław-Warszawa-Kraków-Gdańsk 1973, s. 109, 442. Łacińską nazwę Aphrodisias powiela Piotr Gruszka (zob. przyp. 2). Czwarta wersja Afrodyzja pojawia się w niektórych opracowaniach, np. Encyklopedia sztuki starożytnej, red. K. MicHAŁOWSKI, Warszawa 1975, s. 34. 
między innymi zwolnienie od podatków². Oktawian August tak sobie upodobał Afrodyzjadę, że uczynił ją swoim miastem³, wyłączył z zarządu prowincji Azji i potwierdził przywileje nadane miastu za czasów Republiki Rzymskiej ${ }^{4}$. W okresie pryncypatu, Afrodyzjada była miastem wolnym ${ }^{5}$, bogatym i jednym $\mathrm{z}$ ważniejszych centrów kultu Afrodyty. Rozkwit i dobrobyt miasta nastąpił dzięki bogatym złożom marmuru, który był eksportowany do wszystkich prowincji cesarstwa ${ }^{6}$. Z Afrodyzjady pochodziło kilku znanych twórców, między innymi Chariton, autor poczytnego romansu, oraz Aleksander z Afrodyzjady, filozof perypatetycki, komentator pism Arystotelesa ${ }^{7}$.

Cesarz Hadrian, panujący w latach 117-138 n.e., nawiązując do rządów Oktawiana Augusta, hojnie wspomagał miasto Afrodyzjadę, między innymi wybudował imponujące łaźnie. Zachowało się kilka jego listów w formie inskrypcji, odkopanych w Afrodyzjadzie, a pochodzących $\mathrm{z}$ różnych lat jego panowania.

Joyce Reynolds opublikowała listy Hadriana wykute w bloku białego marmuru odkrytego w 1994 r. $^{8}$ :

2 P. Gruszka, Aphrodisias, "Acta Universitatis Wratislaviensis. Antiquitas» 19/1994, s. 39.

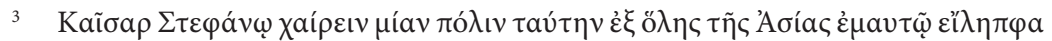
„Cezar [= Oktawian] pozdrawia Stefana: Jedno to miasto z całej Azji wziąłem dla siebie”. Tekst grecki przytaczam za: J. Reynolds, Aphrodisias and Rome, London 1982, s. 96, dok. 10 .

4 L.M. Manconi, L'agora sud di Afrodisia in Caria, Cagliari 2014, s. 21.

5 Plin., Nat. hist. 5,29,109: Longinquiores eodem foro disceptant ... Aphrodisienses liberi. Nieco dalej od tego okręgu sądowniczego znajdują się mieszkańcy wolnego miasta Afrodisias Gajusz Pliniusz Sekundus, Historia naturalna, I: Kosmografia i geografia, ks. II-VI, I. MiкоŁajczyк (red.), I. MiкоŁajczy к, N. Rataj, E. Twarowska-Antczak, K. Antczak (przekład i komentarz), Toruń 2017, s. 398-399.

6 M. SAtre, Wschód rzymski, przeł. S. Rościcki, Wrocław 1997, s. 337. Szerzej na ten temat rozprawia K.T. ERIM, The School of Aphrodisias, «Archaeology» 20/1967, s. 18-27.

Aleksander z Afrodyzji, O duszy, przekład M.E. Komsta, Kraków 2013, s. 10-11.

8 J. Reynolds, New letters from Hadrian to Aphrodisias: trials, taxes, gladiators and an aqueduct, «JRA»13/2000, s. 5. 
Inskrypcja:

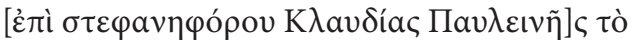

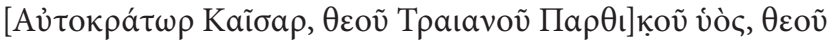

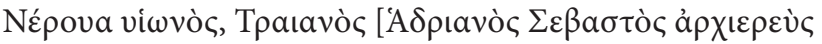

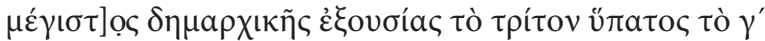
[A

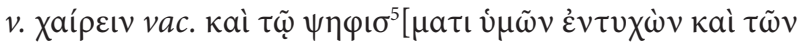

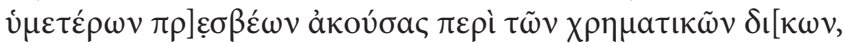

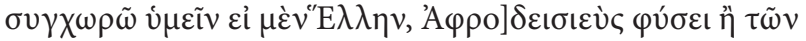

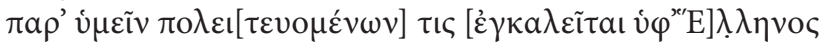

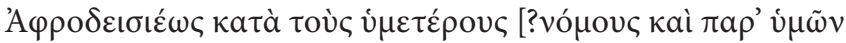

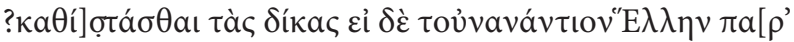

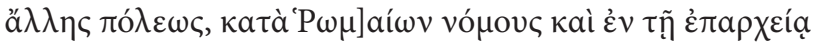

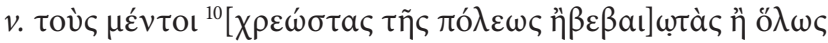

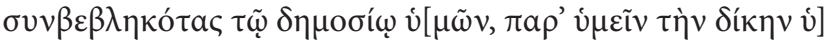

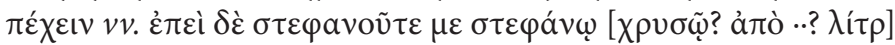

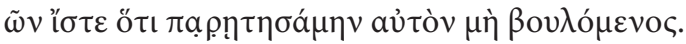

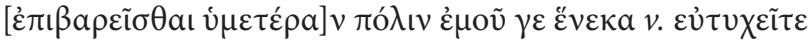

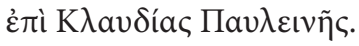

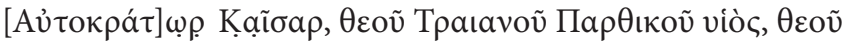

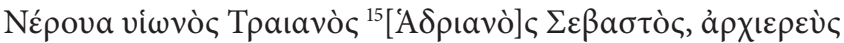

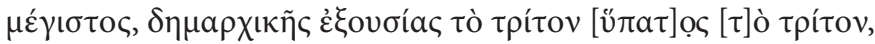

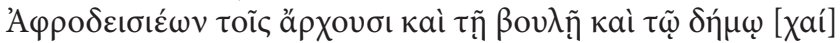

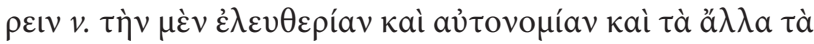

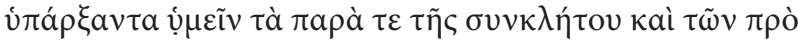

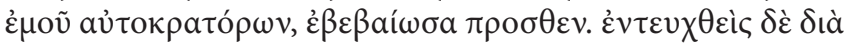

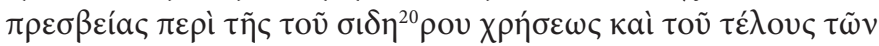

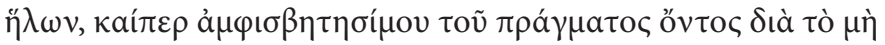

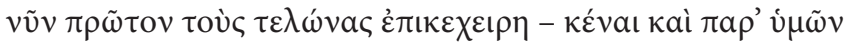

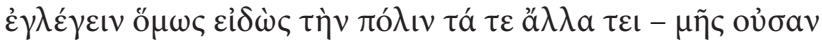

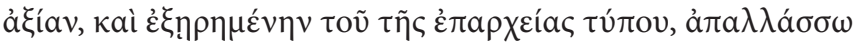

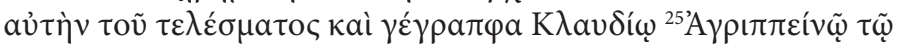

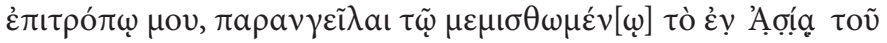

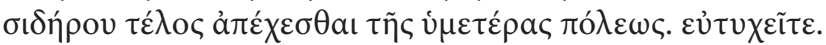




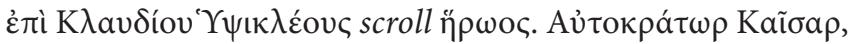

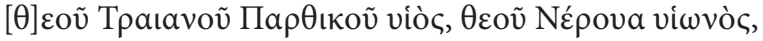

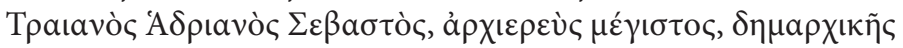

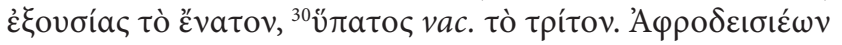

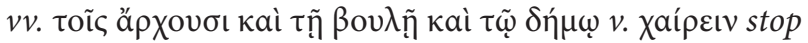

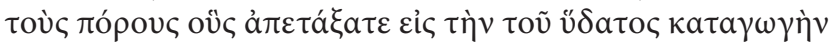

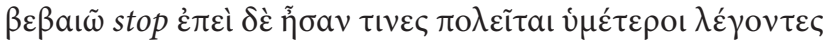

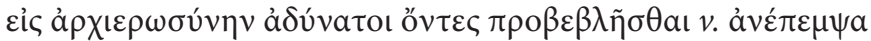

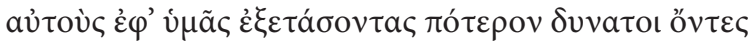

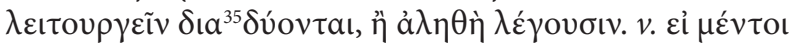

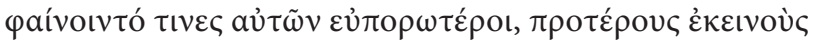

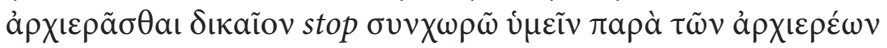

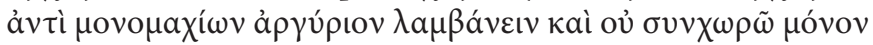

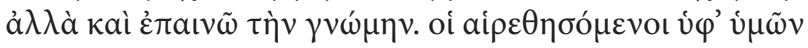

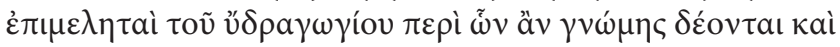

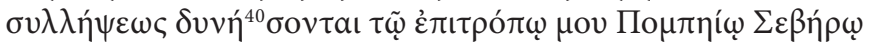

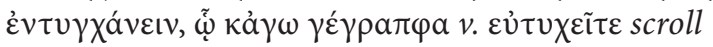

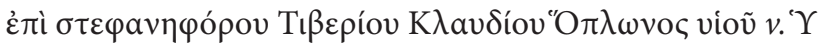
$\psi(\kappa \lambda$ Éovৎ

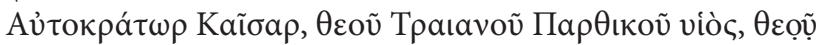

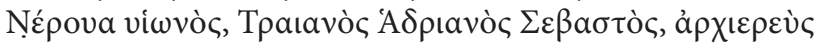

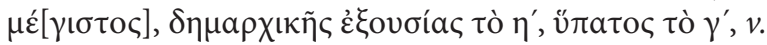

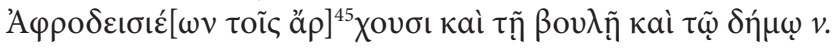

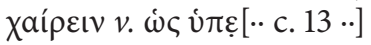

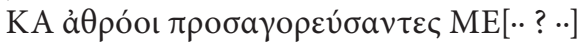

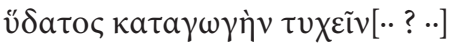

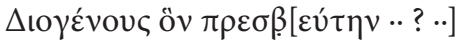

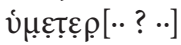

$[\cdot . \cdot . \cdot$

Za stefaneforatu Klaudii Pauliny list pierwszy

List 1 z 119 r. po Chr.: Imperator Cezar, syn boskiego Trajana Partyjskiego, wnuk boskiego Nerwy, Trajan Hadrian August, kapłan najwyższy, mający władzę trybuńską po raz trzeci, konsula po raz trzeci, pozdrawia urzędników, członków rady miejskiej, lud Afrodyzjady. Po otrzymaniu waszej uchwały i wysłuchaniu waszych posłów odnośnie do zobowiązań 
pieniężnych, pozwalam wam, żeby Grek, jeżeli jest obywatelem Afrodyzjady z urodzenia albo przez adopcję, a jest ścigany sądownie przez Greka, który jest obywatelem Afrodyzjady, był sądzony według waszych praw i u was. Przeciwnie, jeżeli Grek pochodzi $z$ innego miasta, to niech będzie sądzony według prawa rzymskiego przed namiestnikiem prowincji. Dłużnicy miasta albo poręczyciele, albo w ogóle ci, którzy zawarli umowę ze skarbem waszego [miasta], niech odbywają rozprawę u was. Skoro zaszczycacie mnie złotym wieńcem o wadze [...] funtów, wiedźcie, że odrzuciłem go, nie chcąc z mojego powodu obciążać finansowo waszego miasta. Niech się wam powodzi.

\section{Za stefaneforatu Klaudii Pauliny}

List 2 z 119 r. po Chr.: Imperator Cezar, syn boskiego Trajana Partyjskiego, wnuk boskiego Nerwy, Trajan Hadrian August, kapłan najwyższy, mający władzę trybuńską po raz trzeci pozdrawia urzędników, członków rady miejskiej, lud Afrodyzjady. Waszą wolność, autonomię i pozostałe prawa uchwalone dla was przez senat i panujących przede mną cesarzy, uprzednio potwierdziłem. Po rozmowie z posłami dotyczącej użycia żelaza i podatku od gwoździ, chociaż ta sprawa jest sporna, przez to nie pierwszy raz poborcy podatków usiłowali ściągać od was podatki mimo tego, że wiedzieli, iż to miasto zostało wyróżnione za zasługi i wyłączone z [regul] zarządzania prowincją, zwalniam je z tego podatku i napisałem do mojego prokuratora Klaudiusza Agryppina, aby rozkazał poborcy podatków w Azji trzymać się z dala od waszego miasta. Niech się wam powodzi.

\section{Za Klaudiusza Hypsiklesa herosa}

List 3 ze 125 r. po Chr.: Imperator Cezar, syn boskiego Trajana Partyjskiego, wnuk boskiego Nerwy, Trajan Hadrian August, kapłan najwyższy, mający władzę po raz dziewiąty, konsul po raz trzeci, pozdrawia urzędników, członków rady miejskiej, lud Afrodyzjady.

Środki pieniężne, który wyznaczyliście na doprowadzenie wody, zatwierdzam. Ponieważ niektórzy twoi obywatele twierdzą, że jako niezdolni do arcykapłaństwa nie mogą podjąć 
się tego zadania, odesłałem ich do was, aby wcześniej wybadać, czy są zdolni, lecz uchylają się od wypełnienia liturgii, czy też mówią prawdę. Jeśli jednak niektórzy z nich okażą się bardzo bogaci, to będzie sprawiedliwie, gdy zostaną najpierw arcykapłanami. Zgadzam się, że wzięliście pieniądze od arcykapłanów [na doprowadzenie wody] zamiast na igrzyska gladiatorskie i nie tylko zgadzam się, ale nawet pochwalam decyzję. Nadzorcy wodociągu, którzy zostaną wybrani przez ciebie w sprawach, w których potrzebują rady, będą mogli uzyskać poradę i pomoc od mojego prokuratora Pompejusza Sewera, do którego już napisałem.

\section{Za stefaneforatu Tyberiusza Klaudiusza Hypsiklesa, syna} Hoplona

List 4 ze 124 r. po Chr.: Imperator Cezar, syn boskiego Trajana Partyjskiego, wnuk boskiego Nerwy, Trajan Hadrian August, kapłan najwyższy mający władzę trybuńską po raz ósmy, konsul po raz trzeci, pozdrawia urzędników, członków rady miejskiej, lud Afrodyzjady. Ponieważ [..] zebrani zwrócili się do mnie, [.......] aby otrzymać [pomoc] przy transporcie wody [...] syn Diogenesa, który [posłował] ....................

\section{Komentarz}

Wers 1: Pierwszy list, podobnie jak i drugi, jest datowany na trzeci rok panowania Hadriana (119 po Chr.).

Zwraca uwagę lokalna datacja listu. Rok lokalny funkcjonujący w Afrodyzjadzie był określony nazwiskiem stefaneforosa ( $\sigma \tau \varepsilon \varphi \alpha v \eta \varphi o ́ \rho \circ \varsigma)$, urzędnika związanego w okresie cesarstwa z kultem władców. Urzędujący stefaneforos pełnił jednocześnie rolę eponima miasta w danym roku, podobnie jak w Atenach archont-eponim ${ }^{9}$. System datowania rocznego według urzędujących eponimów był rozpowszechniony w świecie

\footnotetext{
9 H. Stier, Stephaneforia, «RE» 3.2/1929, kol. 2343-2347.
} 
greckim $^{10}$. Z listu Hadriana dowiadujemy się, że w roku 119 po Chr. funkcję stefaneforii ( $\sigma \tau \varepsilon \varphi \alpha v \eta \varphi o \rho i \alpha)$ pełniła kobieta - Klaudia Paulina ${ }^{11}$. Warto podkreślić, że w Afrodyzjadzie kobiety kilkakrotnie zajmowały urząa stefaneforosa, niektóre z powodu zasług dla miasta były honorowane tym urzędem po śmierci (post mortem) ${ }^{12}$. Nie ulega wątpliwości, że Klaudia Paulina wywodziła się z miejscowej rodziny patrycjuszowskiej, której przedstawiciele otrzymali obywatelstwo rzymskie, przypuszczalnie jako jedni z nielicznych ${ }^{13}$. Imię Klaudia jasno wskazuje, że odbiorczyni listu należała do rodu Klaudiuszów (gens Claudia), co z kolei sugeruje, że jej przodkowie otrzymali obywatelstwo rzymskie za panowania cesarza Klaudiusza albo ewentualnie Nerona ${ }^{14}$.

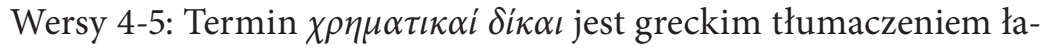
cińskiego actiones pecuniariae. Pojawia się on w źródłach niezwykle rzadko. W okresie panowania Antoninów występuje dwa razy. Po raz drugi spotykamy się z tym greckim terminem $\mathrm{w}$ dekrecie namiestnika Egiptu ze 136 r. po Chr., dotyczącym sporu finansowego między ojcem a jego córką ${ }^{15}$. Nawiązanie do actiones pecuniariae można zaobserwować w biografii Polemona w Żywotach Sofistów Flawiusza Filostrata ${ }^{16}$. Domitilla Campanile zwróciła uwagę, że Polemon doradzał obywatelom Smyrny, aby w sprawach dotyczących sporów finansowych procesowali

10 E. Wipszycka, Chronologia, [w:] Vademecum historyka starożytnej Grecji i Rzymu, red. E. WIPsZYCKA, I, Warszawa 1983, s. 314.

${ }^{11}$ Imię odbiorczyni w pełni zachowało się przy drugim liście, przy pierwszym jest przekonująco restytuowane.

12 I. Bourtzina kou, Die Prosographie von Aphrodisias, Heidelberg 2012, s. 25.

13 I. Bourtzinakou, op. cit., s. 293, nr 1980.

14 B. Holtheide, Römische Bürgerrechtspolitik und römische Neubürger in der Provinz Asia, Freiburg 1983, s. 56-57, 67.

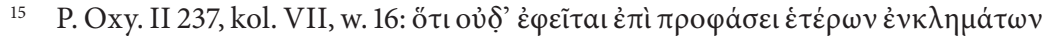

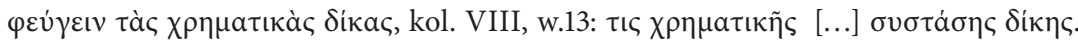
Obszerną analizę tego dokumentu prezentują C. Kreutzsaler, J. Urbanik, Humanity and Inhumanity of Law. The Case of Dionysia, «JJP» 38/2008, s. 119-155.

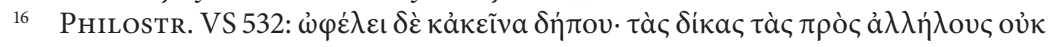

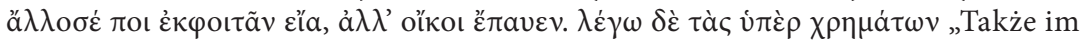
się pomógł, że nie pozwolił, by spory sądowe, jakie prowadziłi ze sobą, wychodziły na zewnątrz, ale by rozstrzygano w domu. Mam na myśli przede wszystkim roszczenia finansowe". 
się w sądach miejskich, a w sporach $\mathrm{z}$ tytułu deliktów przed sądami rzymskimi. Zarówno Hadrian, jak i Polemon wzywają obywateli obu miast (Afrodyzjady i Smyrny), aby spory o kwestie finansowe rozstrzygali przed lokalnymi sądami ${ }^{17}$.

Wersy 6-10: Następnie cesarz odpowiada Afrodyzyjczykom, że mogą dochodzić swoich praw przed sądami Afrodyzjady, jeżeli są obywatelami Afrodyzjady czy to z urodzenia, czy przez adopcję. Natomiast proces powinien toczyć się przed namiestnikiem prowincji według prawa rzymskiego, jeżeli spór finansowy dotyczy obywatela Afrodyzjady i Greka pochodzącego $z$ innego miasta. Termin Grek ('E $\lambda \lambda \eta \nu$ ) w liście Hadriana teoretycznie wykluczał inne narodowości, na przykład Żydów, którzy w tym czasie zamieszkiwali Afrodyzjadę i odgrywali niemałą rolę w życiu miasta ${ }^{18}$. Od czasów panowania dynastii flawijskiej wzrosła znacznie liczba mieszkańców Afrodyzjady, którzy posiadali obywatelstwo rzymskie, ich zatem list Hadriana nie dotyczył. Oczywiście, Rzymianie, będący jednocześnie obywatelami Afrodyzjady, mogli wyrazić wolę, aby ich traktowano jako Afrodyzyjczyków przed sądem lokalnym ${ }^{19}$.

Wersy 11-12: W końcowej części listu Hadrian odrzuca złotą koronę (aurum coronarium), ofiarowaną mu przez miasto. Jako przyczynę podał, że nie chce obciążać finansowo miasta obowiązkową daniną. Korony składano z różnych okazji, na przykład zwycięstwa, wstąpienia na tron, urodzenia następcy. Daniny te były bardzo uciążliwe dla miast i odrzucenie złotego wieńca przez Hadriana wiązało się z brakiem obciążeń finansowych Afrodyzjady. Dbanie o finanse miast i prowincji było wolą cesarza $^{20}$, który wielokrotnie odsyłał złote korony ${ }^{21}$.

Drugi list również jest datowany na 119 r. po Chr.

17 D. CAmpanile, Noterelle ai nuovi documenti da Afrodisia, «ZPE» 135/2001, s. 136-137.

18 J. Reynolds, New letters from Hadrian to Aphrodisias..., s. 13. G. GILbERT, Jewish involvement in ancient civic live: the case of Aphrodisias, «RB»113.1/2006, s. 18-36.

19 Ibidem; J. Reynolds, New letters from Hadrian to Aphrodisias..., s. 13.

20 SHA, Had. 6,5: aurum coronarium Italiae remisit, in provinciis minuit.

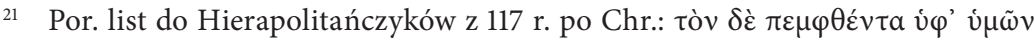

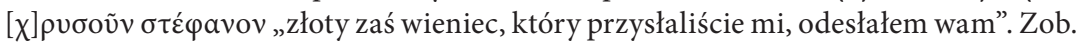
K. Tadajczy K, Epistula Hadriani 'ad Pergamenos', "Zeszyty Prawnicze» 20.3/2020, s. 339 . 
Został napisany prawdopodobnie w Kampanii, gdzie władca podówczas przebywał ${ }^{22}$. Zachował się w dwóch kopiach. Pierwsza z nich, odkryta w roku 1967 w ruinach teatru Afrodyzjady, została skomentowana przez J. Reynolds ${ }^{23}$. Druga, odnaleziona w roku 1994, wydaje się wcześniejsza i bardziej wierna oryginałowi. Pomiędzy kopiami występują nieznaczne różnice (głównie dotyczące zastosowanych skrótów), które nie wpływają na ogólne znaczenie i sens dokumentu ${ }^{24}$.

Wersy 13-15: Te linie są powtórzeniem początkowych wersów inskrypcji. Zawierają tytulaturę Hadriana.

Wersy 16-17: Hadrian potwierdził autonomię, wszystkie prawa i przywileje nadane przez republikę rzymską i poprzednich pryncepsów. Praktyka ta była standardowa, zachowało się parę innych listów Hadriana potwierdzających przywileje nadane przez wcześniej panujących władców $^{25}$. Fergus Millar sądzi, że istniał jeden edykt generalny Hadriana potwierdzający przywileje wszystkich miast ${ }^{26}$.

Wers 18 wspomina o posłach. Zwykle są oni wymieniani z imienia i nazwiska na końcu listu. Tym razem wzmianka o posłach jest w środku listu. Można zauważyć, że posłowie Afrodyzjady spotkali się z samym cesarzem, a nie z komisją senatu, a przecież prowincja Azja, w której leżała Afrodyzjada, była prowincją senatorską. Christos Grammatikas wskazuje, że ten stan trwał od dawna i władze miast zamiast $\mathrm{z}$ komisjami senatu spotykały się bezpośrednio z ważnymi urzędnikami albo cesarzami ${ }^{27}$.

Wersy 18-20: Główną zawartością listu jest zwolnienie z podatku od wydobycia żelaza i wyrobu gwoździ. Podatek od gwoździ wymieniany jest tylko w tym jednym źródle. Nie wiadomo, kiedy ten podatek został wprowadzony. Mogło się to wydarzyć albo za panowania Wespazjana po

\footnotetext{
22 A.R. Birley, Hadrian cesarz niestrudzony, Warszawa 2002, s. 163.

23 J. Reynolds, Aphrodisias and Rome, s. 115-118.

24 J. Reynolds, New letters from Hadrian to Aphrodisias..., s. 15.

25 Np. Epistula Hadriani Astypalaensibus, Epistula Hadriani ad Delphis.

26 F. Millar, The Emperor in the Roman World (31B.C.-A.D.337), London 1977,

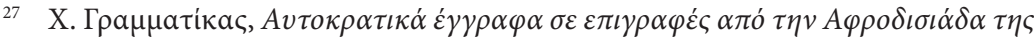

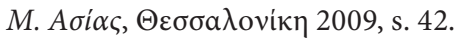
s. 414 , p. 17. 
wojnie domowej w 69 r. po Chr., albo za rządów Domicjana z powodu trudności finansowych państwa, albo też za Trajana, aby sfinansować jego politykę podboju wschodu ${ }^{28}$. Istnieje tylko jedna wzmianka o wydobywaniu żelaza w górach Taurus w tamtej okolicy. Jest ona dosyć późna i pochodzi z okresu późnego cesarstwa. Wzmianka ta pojawia się w liście św. Bazylego do Modesta prefekta z 372 r. po Chr. ${ }^{29}$ Joyce Reynolds sugeruje, że rudę żelaza importowano do Afrodyzjady. Z kolei Louis Robert, opierając się na współczesnych badaniach geologicznych, twierdzi autorytatywnie, że rudę żelaza wydobywano w okolicy Afrodyzjady ${ }^{30}$.

Wersy 21-22: Cesarz uspokaja obywateli Afrodyzjady i potwierdza im zwolnienia podatkowe, wskazując przy okazji, że Afrodyzjada zawsze była wierna Rzymowi. Hadrian w początkowym okresie panowania potwierdzał wyłącznie dawne zwolnienia podatkowe, ale nie nadawał nowych ${ }^{31}$.

Wersy 24-26: Werner Eck sądzi, że Klaudiusz Agryppin może być identyczny z prokuratorem Arsinoe w Egipcie, wymienianym w PIR C ${ }^{2}$ $776^{32}$. Graham Burton stawia śmiałą tezę, że już na początku II w. po Chr. prokuratorzy, którzy zarządzali prowincjami senatorskimi, nie tylko zajmowali się majątkami cesarskimi, lecz także byli odpowiedzialni za pobór podatków, tak jak prokuratorzy w prowincjach cesarskich. Ich rola została zatem zrównana $\mathrm{z}$ prokuratorami prowincji cesarskich ${ }^{33}$. Joyce Reynolds jest bardziej ostrożna, gdyż uważa, że jedno zachowane

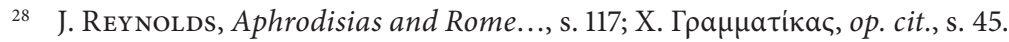

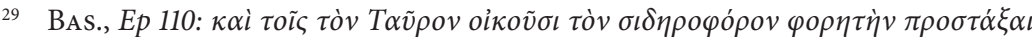

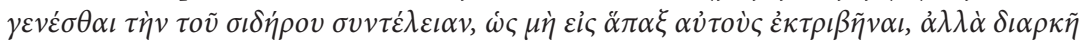

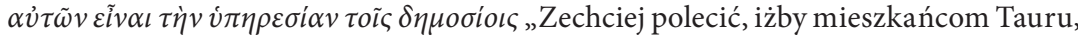
dostarczającego żelazo, zmniejszono daninę uiszczaną w żelazie tak, żeby mogli ją uiścić. Spraw, by nie zostali doprowadzeni do zupełnej ruiny, ale niech długo jeszcze świadczą usługi dla publicznego dobra”. Zob. Bazyli Wielki, Listy, przekład W. KrzyżNIAK, Warszawa 1972, s. 147.

30 L. Robert, Documents d'Asie Mineure, «BCH» 107.1/1983, s. 509-511.

31 T.M. BoAtwright, Hadrian and the Cities of the Roman Empire, Princeton 2002, s. 88-90.

32 W. Eck, Zur Erhebung der Erbschafts- und Freilassungssteuer in Ägypten im 2. Jahrh. n. Chr., «ZPE» 27/1977, s. 206.

33 G. Burton, Provincial Procurators and the Public Provinces, «Chiron» 23/1993, s. 18 . 
źródło nie daje prawa do stawiania takiej hipotezy. Na podstawie tych pośrednich dowodów wydaje się nierozsądne sugerowanie, że w czasach Hadriana prokurator był odpowiedzialny za całość poboru podatków pośrednich w Azji, tym bardziej że natura tego podatku pozostaje niejasna $^{34}$.

Trzeci list datuje się na rok 125 po Chr.

W tym roku eponimem był Tyberiusz Klaudiusz Hypsikles, który został określony przydomkiem hērōs (gr. ṇp $\omega \varsigma)^{35}$. Pełnił on wtedy urząd stefaneforosa w Afrodyzjadzie. Identyczne miano nosi adresat listu czwartego Tyberiusz Klaudiusz Hypsikles, syn Hoplona ${ }^{36}$, który był stefaneforosem rok wcześniej. Joyce Reynolds sądzi, że to były dwie różne osoby pełniące kolejno tę funkcję, podczas gdy Angelos Chaniotis wyraża przeciwne stanowisko, uznając, że urząd stefaneforosa pełniła przez dwa kolejne lata ta sama osoba. Istnieje relatywnie małe prawdopodobieństwo, aby dwie różne osoby o identycznym nazwisku sprawowały ten sam urząd rok po roku. Hypsikles zmarł w czasie urzędowania w następnym roku i z tego powodu nadano mu przydomek herosa ${ }^{37}$.

Wersy 31-32: Hadrian od razu przechodzi do sedna sprawy i bez żadnego wstępu zatwierdza środki finansowe na doprowadzenie wody. W gestii cesarza leżało zatwierdzenie kosztownej budowy wodociągów. Ponieważ list czwarty związany jest $\mathrm{z}$ budową akweduktu w Afrodyzjadzie, wydaje się, że list trzeci nawiązuje do tej samej inwestycji, czyli dotyczy budowy nowego wodociągu w mieście. Afrodyzjada posiadała już wodociąg zbudowany za czasów panowania Domicjana ${ }^{38}$, który nie był wystarczający w stosunku do potrzeb. Z tego powodu za czasów Hadriana zaczęto budować nowy, duży wodociąg, który miał prowadzić

34 J. Reynolds, Aphrodisias and Rome, s. 118.

35 I. Bourtzinakou, op. cit., s. 324, nr 2232.2.

36 Ibidem, s. 324, nr 2232.1.

37 A. Chaniotis, New Inscriptions from Aphrodisias (1995-2001), «JRA»108/2004, s. 406-407.

38 K.M. Coleman, Exchanging gladiators for an aqueduct at Aphrodisias (SEG 50.1096), «Acta Classica» 51/2008, s. 40. 
wodę z rzeki Timeles ${ }^{39}$. Miasto wchodziło w szczytowy okres rozwoju, a doprowadzenie wody mogło być związane z budową tak zwanych łaźni Hadriana. Nie ulega wątpliwości, że cesarz Hadrian dbał o zaopatrzenie licznych miast w wodę ${ }^{40}$. Imperator rzymski musiał zatwierdzić plan budowy nowego akweduktu. Świadczy o tym zachowana korespondencja między Pliniuszem Młodszym a cesarzem Trajanem, dotycząca wyrażenia zgody na budowę wodociągów w Nikomedii i Synopie. W pierwszym przypadku Pliniusz zwraca się o akceptację nowego planu budowy, ponieważ mieszkańcy Nikomedii na skutek zaniedbania nie dokończyli budowy dwóch poprzednio zaprojektowanych akweduktów. Cesarz nakazuje przeprowadzić dokładne dochodzenie w tej sprawie, a następnie wydaje zgodę. Drugi przypadek jest mniej skomplikowany. Trajan wyraża zgodę, tym bardziej że wodociąg ma być w całości sfinansowany z budżetu miasta Synope ${ }^{41}$.

39 A.R. Commito, F. Rojas, The Aqueducts of Aphrodisias, «Aphrodisias. The Aphrodisias Regional Survey» 5/2012, s. 289-291.

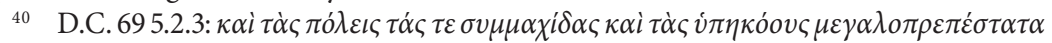

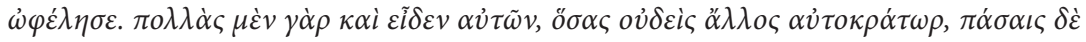

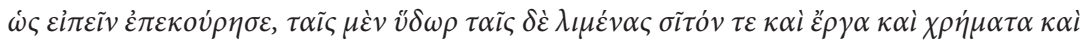
$\tau \iota \mu \dot{\alpha} \varsigma \not \partial \lambda \lambda \alpha \iota \varsigma \not ̉ \lambda \lambda \alpha \varsigma \delta \iota \delta o v ́ \varsigma$ „wspierał miasta, sprzymierzeńców, poddanych bardzo hojnie. Zobaczył nawet wiele spośród nich, więcej niż jakikolwiek inny cesarz, pomagał w biedzie wielu z nich, dając jednym zaopatrzenie w wodę, innym porty, zboże, budowle publiczne, pieniądze i inne zaszczyty”. SHA Had., 20,5: Aquarum ductu etiam infinitos hoc nomine nuncupavit „Tym imieniem nazwał także niezliczonej ilości wodociągów”.

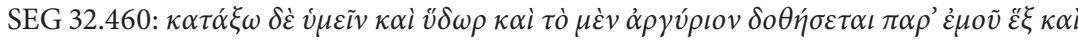

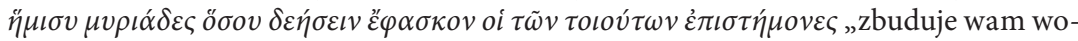
dociąg i dostaniecie pieniądze ode mnie, a fachowcy mówią, że potrzeba 60,5 tysięcy denarów”.

${ }^{41}$ Plin. Ep. 10,91: Neque enim dubitandum puto, qui aqua perducenda sit in coloniam Sinopensem, si modo et viribus suis assequi potest, cum plurimum ea res et salubritati et voluptati eius collatura sit „Nie mam wątpliwości, że wodę należy sprowadzić do Synopy, skoro miasto jest w stanie przeprowadzić to własnym sumptem, a inwestycja przyczyni się do poprawy zdrowia i samopoczucia mieszkańców”. Tł. A. DĘBıński, M. JońCA, I. Ler ACZyK, A. ŁukA, [w:] Korespondencja Pliniusza Młodszego z cesarzem Trajanem, tekst, tłumaczenie A. DęBiński, M. JońcA, I. Leraczy , A. ŁukA, Lublin 2017, s. 379. 


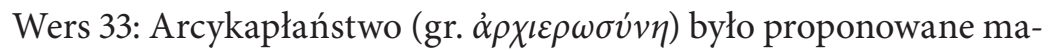
jętnym obywatelom, który byli zobowiązani pokrywać koszty uroczystości i igrzysk gladiatorskich. Tytuł arcykapłana ả $\rho \chi\llcorner\varepsilon \rho \varepsilon v ́ c$ odnosił się do kapłanów kultu cesarskiego, a nie kapłanów bogini Afrodyty. Kult

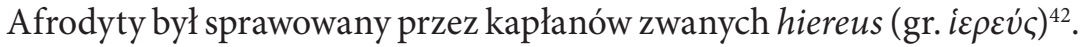

Wersy 34-36: W kolejnych wersach listu Hadrian porusza problem obsadzenia stanowiska arcykapłanów kultu cesarskiego. Niektórzy obywatele Afrodyzjady zgłosili problem podjęcia tej funkcji z powodów nadmiernych obciążeń finansowych. Arcykapłaństwo wiązało się z organizowaniem kosztownych widowisk, w tym walk gladiatorskich. Sprawowanie liturgii i euergetyzmu w świecie grecko-rzymskim stanowiło ważną funkcję społeczną. Z jednej strony, funkcja dawała wielki prestiż arcykapłanom i ich rodzinom jako dobroczyńcom miasta, a z drugiej strony, wiązała się z uciążliwymi i dużymi wydatkami finansowymi. Niechęć obywateli, mogących sprostać zadaniom arcykapłanów, do sprawowania tej funkcji można tłumaczyć także tym, że sława fundatora igrzysk była krótkotrwała, a wydatki z nimi związane zazwyczaj stawały się ogromne (jeśli uwzględnić nie tylko walki gladiatorów, lecz także walki ze zwierzętami, które trzeba było sprowadzić) ${ }^{43}$. Cesarz Hadrian nakazuje jednak przeprowadzenie dochodzenia i zaleca, że kandydaci powinni zostać arcykapłanami, o ile spełniają kryteria majątkowe.

Wersy 37-38: Hadrian zaaprobował przesunięcie pieniędzy przeznaczonych na igrzyska gladiatorów na budowę wodociągu. Nie ma wzmianek w źródłach, że nie akceptował walk na arenie i miał do nich szczególną niechęć ${ }^{44}$. Starożytność pogańska nie miała moralnego oporu co do igrzysk ${ }^{45}$. Nie kierował się tu przesłankami etycznymi

42 L.R. Brody, The Cult of Aphrodite an Aphrodisias in Caria, «Kernos» 14/2001, s. 103.

43 K.M. Coleman, Exchanging gladiators for an aqueduct at Aphrodisias (SEG 50.1096), «Acta Classica» 51/2008, s. 39.

${ }^{44}$ K. Amielańczy , Rzymskie prawo karne $w$ reskryptach cesarza Hadriana, Lublin 2006, s. 260.

45 P. Veyne, Imperium grecko-rzymskie, przeł. P. Domański, Kęty 2008, s. 546. 
czy humanitarnymi ${ }^{46}$, lecz wyłącznie finansowymi. Ten fragment listu wskazuje, że arcykapłani związani z kultem cesarskim zajmowali się organizacją igrzysk ${ }^{47}$, a każdorazowe przesunięcie środków finansowych, przeznaczonych na walki gladiatorów, na inne cele (np. roboty publiczne) wymagało poinformowania cesarza i pozyskania jego zgody ${ }^{48}$.

Wersy 39-40: Na zakończenie listu cesarz informuje mieszkańców Afrodyzjady, że osoby, wybrane do nadzorowania budowy nowego wodociągu, mogą się zwrócić o pomoc i wskazówki do prokuratora prowincji Azji, który został już powiadomiony o tej inwestycji. Pompejusz Sewer, który był prokuratorem Azji w tym czasie ${ }^{49}$, pojawia się jeszcze w liście cesarza do Stratoniki Hadrianopolis z 127 r. po Chr. ${ }^{50}$

Czwarty list zachował się bardzo uszkodzony.

Wersy 42-44: Tylko tytulatura Hadriana i wersy zawierające prośbę o pomoc przy budowie wodociągu są dobrze zachowane. Reszta listu została stracona i nie daje się odtworzyć. Podana tytulatura jasno wskazuje, że list czwarty wysłano w roku sprawowania przez Hadriana trybunatu ludowego po raz ósmy (od grudnia 123 r. do grudnia 124).

Wersy 46-47: Zawierały też z pewnością prośbę o zezwolenie na budowę i dofinansowanie wodociągu, jak świadczą zachowane fragmenty

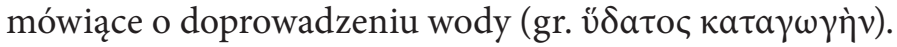

46 K. Amielańczyк, Reskrypt cesarza Hadriana o zakazie sprzedaży niewolnic stręczycielom i niewolników właścicielom szkół gladiatorskich, [w:] Contra leges et bonos mores. Przestępstwa obyczajowe w starożytnej Grecji i Rzymie, red. H. Kowalski, M. KuryŁowicz, Lublin 2005, s. 21-22.

47 D. CAmpanile, Noterelle ai nuovi documenti da Afrodisia, «ZPE» 135/2001, s. 138.

48 D. 50,10,3 pr.: Publico vero sumptu opus novum sine principis auctoritate fieri non licere constitutionibus declaratur „W rozporządzeniach cesarskich stanowi się, że nowa budowla na koszt gminy miejskiej nie może powstać bez zgody cesarza”. Zob. Digesta Iustiniani. Digesta Justyniańskie, tekst i przekład VII.2 księgi 48-50, red T. PAlmirski, Kraków 2017, s. 333.

49 H. Wolf, Pompeius 116, «RE» 21.2/1952, kol. 2289.

50 H. Oliver, Constitutions of Early Roman Emperors from Inscriptions and Papyri, Philadelphia 1989, s. 202, nr 79. 


\section{'Epistulae Hadriani ad Aphrodisienses' Listy Hadriana DO AFRODYZYJCZYKów}

\section{Streszczenie}

Celem artykułu jest przedstawienie tłumaczenia i komentarza do listów Hadriana do karyjskiej Afrodyzjady i polityki cesarza względem tego wolnego miasta. W liście pierwszym Hadrian potwierdza autonomię sądowniczą obywateli Afrodyzjady, w drugim akceptuje przywileje nadane przez poprzednich władców i zwalnia ich z podatku od rud żelaza. Dwa ostatnie listy dotyczą zgody władcy na budowę nowego wodociągu i przesunięcia pieniędzy przeznaczonych na igrzyska gladiatorskie na doprowadzenie wody do miasta oraz uchylania się ludzi od wyboru na kapłanów kultu cesarskiego i wypełniania obowiązków związanych $\mathrm{z}$ tą funkcją.

\section{‘Epistulae Hadriani ad Aphrodisienses' Hadrian's letters to THE APHRODISIANS}

\section{Summary}

The aim of this article is to present the translation and commentary to Hadrian's epistles to Aphrodisias in Caria, and his policy on this Greek free city. In his first letter, Hadrian confirms the judicial autonomy of the citizens of Aphrodisias. In the second letter, he recognises the privileges granted to the city by his predecessors and exempts the Aphrodisians from the tax on iron ore. In the last two letters, he issues his consent to the construction of a new aqueduct and to the transfer of funds originally allocated for the organisation of gladiator games to supply the city with water. He also writes about citizens evading election to the priest's office for the performance of the imperial cult and the other duties associated with the office.

Słowa kluczowe: cesarz Hadrian; proces; gladiator; podatek; wodociąg. 
Keywords: the Emperor Hadrian; trial; gladiator; tax; aqueduct.

\section{Literatura}

AmielańCZy к K., Reskrypt cesarza Hadriana o zakazie sprzedaży niewolnic stręczycielom i niewolników właścicielom szkót gladiatorskich, [w:] 'Contra leges et bonos mores'. Przestępstwa obyczajowe w starożytnej Grecji i Rzymie, red. H. KoWALSKI, M. KuRYŁOWICZ, Lublin 2005, s. 9-23.

AmielańCZyк K., Rzymskie prawo karne w reskryptach cesarza Hadriana, Lublin 2006.

Bazyli Wielki, Listy, przekład W. KrzyżniaK, Warszawa 1972.

BIRLEY A.R., Hadrian cesarz niestrudzony, Warszawa 2002.

Boatwright T.M., Hadrian and the Cities of the Roman Empire, Princeton 2002. Bourtzinakou I., Die Prosographie von Aphrodisias, Heidelberg 2012.

Brody R.L., The Cult of Aphrodite an Aphrodisias in Caria, «Kernos» 14/2001, s. 93-109.

Burton G., Provincial Procurators and the Public Provinces, «Chiron» 23/1993, s. $13-28$.

Campanile D., Noterelle ai nuovi documenti da Afrodisia, «ZPE»135/2001, s. 136-138.

Chaniotis A., New Inscriptions from Aphrodisias (1995-2001), «JRA» 108/2004, s. 377-416.

Coleman M.K., Exchanging gladiators for an aqueduct at Aphrodisias (SEG 50.1096), «Acta Classica» 51/2008, s. 31-46.

Cомmito R.A., Rojas F., The Aqueducts of Aphrodisias, «Aphrodisias V. The Aphrodisias Regional Survey» 2012, s. 239-307.

Digesta Iustiniani. Digesta Justyniańskie, tekst i przekład VII.2 księgi 48-50, red T. PAlmirski, Kraków 2017.

Eск W., Zur Erhebung der Erbschafts- und Freilassungssteuer in Ägypten im 2. Jahrh. n. Chr., «ZPE» 27/1977, s. 201-209.

ERIM K.T., The School of Aphrodisias, «Archaeology» 20/1967, s. 18-27.

GILBERT G., Jewish involvement in ancient civic live: the case of Aphrodisias, «RB» 113.1/2006, s. 18-36.

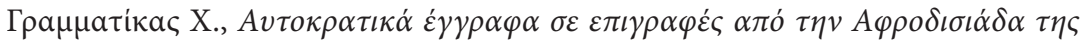

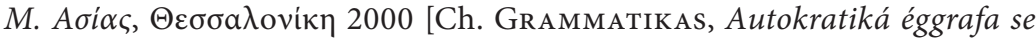
epigrafés apó tin Afrodisiáda tis M. Asias, Thessaloníki 2009].

Gruszka P., Aphrodisias, «Acta Universitatis Wratislaviensis. Antiquitas» 19/1994, s. 37-45. 
Holtheide B., Römische Bürgerrechtspolitik und römische Neubürger in der Provinz Asia, Freiburg 1983.

Korespondencja Pliniusza Młodszego z cesarzem Trajanem, tekst, tłumaczenie A. Dębiński, M. Jońca, I. Leraczyk, A. Łuka, Lublin 2017.

Kreutzsaler C., Urbanik J., Humanity and Inhumanity of Law: The Case of Dionysia, «JJP» 38/2008, s. 119-155.

Manconi L.M., L'agora sud di Afrodisia in Caria, Cagliari 2014.

Millar F., The Emperor in the Roman World (31B.C.-A.D.337), London 1977.

Oliver H., Constitutions of Early Roman Emperors from Inscriptions and Papyri, Philadelphia 1989.

RATTÉ CH., The founding of Afrodisias, «JRA Suppl» 70/2008, s. 7-35.

ReYnolds J., Aphrodisias and Rome, London 1982.

Reynolds J., New letters from Hadrian to Aphrodisias: trials, taxes, gladiators and an aqueduct, «JRA»13/2000, s. 5-20.

Robert L., Documents d'Asie Mineure, «BCH» 107.1/1983, s. 509-511.

TadajCzy K K., Epistula Hadriani 'ad Pergamenos', «Zeszyty Prawnicze» 20.3/2020, s. 497-599.

Tytus Liwiusz, Dzieje Rzymu od założenia miasta, księgi XXXV-XL, M. Brożek (przekład), M. Brożek, J. Wolski (komentarz), Wrocław-Warszawa-Kraków-Gdańsk, Łódź 1981.

Veyne P., Imperium grecko-rzymskie, przeł. P. Domańsкi, Kęty 2008.

Wipszycka E., Chronologia, [w:] Vademecum historyka starożytnej Grecji i Rzymu, red. E. WipszycKa, I, Warszawa 1983, s. 305-321.

Wolf H., Pompeius 116, «RE» 21.2/1952, kol. 2289. 